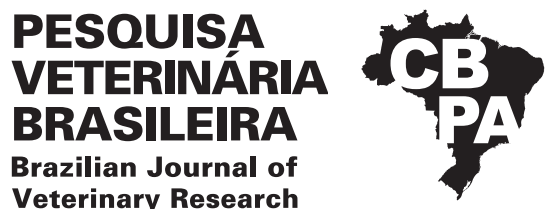

\title{
Use of bone marrow for detection of toxic chemicals for the elucidation of poisoning in forensic veterinary medicine ${ }^{1}$
}

\author{
Sóstenes A.C. Marcelino² (D), Rogéria Serakides², Viviane N. Castro-Silva ${ }^{2}$, \\ Maria L. Ramos ${ }^{2}$, Natália M. Ocarino ${ }^{2}$ and Marília M. Melo ${ }^{2 *}$ (D)
}

\begin{abstract}
Marcelino S.A.C., Serakides R., Castro-Silva V.N., Ramos M.L., Ocarino N.M. \& Melo M.M. 2020. Use of bone marrow for detection of toxic chemicals for the elucidation of poisoning in forensic veterinary pathology. Pesquisa Veterinária Brasileira 40(10):798803. Escola de Veterinária, Universidade Federal de Minas Gerais, Av. Presidente Antônio Carlos 6627, Belo Horizonte, MG 31275-013, Brazil. E-mail marilia.melo@pq.cnpq.br

In forensic toxicology, the detection of toxic chemicals from human bone marrow is often used in cases with an extended post mortem interval; however, in veterinary medicine, this practice is not used. Therefore, this study was performed to investigate the suitability of bone marrow for toxicological analysis in dogs and cats. Six animals with suspected poisoning were selected; the carcasses were sent for necropsy, and the organs were collected and preserved in buffered formalin and processed routinely for histological examination. In addition, bone marrow samples from the femur, humerus, and tibia were collected for toxicological analysis by liquid chromatography coupled to mass spectrometry detection (LC-MS). This analysis confirmed the presence of aldicarb, aldicarb sulfone, asulam, carbendazim, chlorpyrifos, dichlorvos, thifensulfuron methyl and trifloxysulfuron-sodium and associated with clinical symptoms and anatomo-histopathological alterations it was recognized the poisonings. It is expected that this study will promote the toxicological investigation of bone marrow and open avenues for the use of this tissue as an option for the detection of toxic chemicals in cases of forensic pathology.
\end{abstract}

INDEX TERMS: Bone marrow, toxic chemicals, poisoning, forensic toxicology, aldicarb, dichlorvos, chlorpyrifos, pesticides, herbicides, crimes.

RESUMO.- [Uso de medula óssea para detecção de produtos químicos tóxicos para a elucidação de intoxicação em patologia veterinária forense]. Na toxicologia forense, a detecção de substâncias químicas tóxicas provenientes da medula óssea humana é frequentemente usada em casos com intervalo post mortem prolongado; no entanto, na medicina veterinária, essa prática não é utilizada. Portanto, este estudo foi realizado para investigar a utilização da medula óssea nas análises toxicológicas em cães e gatos. Seis animais com suspeita de intoxicação foram selecionados; as carcaças foram enviadas para necropsia e os órgãos foram coletados e preservados em formalina tamponada e processados rotineiramente para exame histológico. Amostras de medula óssea de fêmur, úmero e tíbia foram coletadas para análise toxicológica por cromatografia líquida acoplada à espectrometria de massa-massa (LC-MS).

\footnotetext{
${ }^{1}$ Received on August 6, 2020.

Accepted for publication on August 20, 2020.

${ }^{2}$ Escola de Veterinária, Universidade Federal de Minas Gerais (UFMG), Av. Presidente Antônio Carlos 6627, Belo Horizonte, MG 31275-013, Brazil. *Corresponding author: marilia.melo@pq.cnpq.br
}

A análise por LC-MS confirmou a presença dos agrotóxicos aldicarbe, aldicarbe sulfona, asulam, carbendazim, clorpirifós, diclorvós, tifensulfuron metil e trifloxisulfuron-sódico, e em associação com sinais clínicos e achados anatomo-histopatológicos comprovou-se as intoxicações. Espera-se que este estudo promova a utilização da medula óssea como uma opção na investigação toxicológica para a detecção de produtos químicos tóxicos em casos de patologia forense.

TERMOS DE INDEXAÇÃO: Medula óssea, produtos químicos tóxicos, intoxicação, toxicologia forense, aldicarbe, diclorvos, clorpirifós, agrotóxicos, herbicidas, crimes.

\section{INTRODUCTION}

Intentional exogenous poisoning is one of the main causes of crimes against animals leading to death. Carbamates and organophosphates are the most common active compounds used in criminal poisoning (Siqueira et al. 2015). Regardless of the toxic chemicals suspected, samples of the stomach contents, kidney, liver and adipose tissues are collected for 
routine toxicological examination. However, carcasses in an advanced state of decomposition or skeletonization can compromise post mortem evaluation and make it difficult to process samples for toxicological analysis because of inadequate soft tissue content (Fukushima et al. 2018).

In such cases, bones have emerged as vital for macroscopic and toxicological evaluations. In forensic science, toxicological examination of human bones, particularly bone marrow, is used for the detection of psychoactive illicit drugs, and some pesticides, involved in cases of suicide, overdose, and poisoning among professionals working with these substances (McIntyre et al. 2000, Drummer 2008, Cartiser et al. 2011). As the bone marrow is located inside the medullary canal, it is protected from external contaminations and the heterolytic actions of putrefying bacteria. Thus, its structure is preserved for a longer period than other tissues (Cartiser et al. 2011) and it was showed that the histological preservation of bone marrow for up to 3 months after death (Grellner \& Glenewinkel 1997).

In addition to its greater resistance to putrefaction, the bone marrow is highly vascular with a high lipid content that favors the accumulation of lipophilic drugs. Owing to these characteristics, bone marrow can be considered as a potential tissue for the toxicological analysis of skeletal bodies or cadavers with extended post mortem intervals (Cartiser et al. 2011).

The first use of bone marrow in forensic toxicology was used to study the kinetics of alcohol (Casier et al. 1943). In the 1980s, further studies examined the correlation between toxic chemicals concentrations in the bone marrow and in the blood of poisoned animal models and humans (Winek \& Esposito 1981, Winek \& Luhanik 1981, Winek \& Janssen 1982, Winek et al. 1982, 1983, 1985). Bone marrow from skeletal remains has only recently been studied to investigate the use of xenobiotics and correlate their use with mortality (Cartiser et al. 2011).

In the study of bone marrow, different collection sites may be used, such as the femur (Winek \& Jones 1980), ribs (Schloegl et al. 2006) or vertebral bodies (Maeda et al. 2006). Nevertheless, a standard sampling procedure has not yet been established in the scientific community. Depending on the lipophilicity of the drug, the concentration may depend on the amount of yellow or red bone marrow present (Cartiser et al. 2011). Many substances such as, ethanol, bromoisoval, diazepam, flurazepam, triazolam, amitriptyline, nortriptyline, desipramine, doxepin, sertraline, moclobemide, cocaine, methamphetamine, amphetamine, morphine and paraquat could be detected in bone marrow (Drummer 2008). However, in veterinary medicine, there are no studies using bone marrow as a site for the detection of toxic chemicals. Thus, the aim of the present study was to investigate toxic chemicals in the bone marrow of dogs and cats with suspected exogenous intoxication.

\section{MATERIALS AND METHODS}

In this study, six animals (three dogs and three cats) were necropsied, and fragments of abdominal and thoracic organs were collected in $10 \%$ buffered formalin for histological analysis. The organs were processed by a routine paraffin inclusion technique, and histological sections of 3-5 $\mu \mathrm{m}$ thickness were stained with hematoxylin and eosin (HE).

The bone marrow of the femur, tibia and humerus was collected of each animal, weighed and a pool was used to toxicological analysis.
Chromatographic analyses were performed using an ultra-fast liquid chromatographic (UFLC) system (Shimadzu LC20) equipped with a binary pump (Shimadzu LC20ADXR), an autosampler (Shimadzu SIL20ACXR), and a column oven (Shimadzu CTO20AC).

Each bone marrow pool was extracted by modified QuEChERS method (Anastassiades et al. 2003). The sample (5.0g) was transferred to a polypropylene tube $(50 \mathrm{~mL})$, following the addition $5.0 \mathrm{~mL}$ of ultrapure water and $10.0 \mathrm{~mL}$ of acetonitrile $/ 0.1 \%$ acetic acid and ethyl acetate $(70: 30, v / v)$, and the mixture was vortexed for 1 minute. Magnesium sulfate $(4.0 \mathrm{~g})$ and sodium acetate $(1.0 \mathrm{~g})$ were added, and the mixture was vortexed for another 1 minute and centrifuged at 4,000 rpm for 11 minutes. Subsequently, the mixture was kept at $-20^{\circ} \mathrm{C}$ overnight (12 hours) in order to break emulsions and then centrifuged at $4,000 \mathrm{rpm},-5^{\circ} \mathrm{C}$, for 5 minutes. The organic layer $(1.0 \mathrm{~mL})$ was transferred to a $2.0 \mathrm{~mL}$ microtube containing $150 \mathrm{mg}$ of anhydrous magnesium sulfate, $30 \mathrm{mg}$ of primary and secondary amine (PSA), and $30 \mathrm{mg}$ of dispersive C18. Tubes were shaken for 1 minute and centrifuged at 4,000 rpm for 12 minutes. The extracts were used for chromatographic analyses.

A total of 171 analytes from different classes was used to study the full scope of the method. All pesticides were evaluated by LCMS using a multiresidue analysis technique and this analysis was carried out using a 5500 Triple Quad mass spectrometer (Applied Biosystems, MDS SCIEX, Ontario, Canada). The instrument was operated using electrospray ionization source (ESI) in positive and negative ion modes. Instrument settings, data acquisition and data processing were controlled by the Analyst software (Version 1.5.1, Applied Biosystems). Source parameters were optimized as follows: ion spray voltage, $5.5 \mathrm{kV}$ for ESI (+) and $4.5 \mathrm{kV}$ for ESI (-); curtain gas, 20psi; collision gas, 8psi; nebulizer gas, $30 \mathrm{psi}$; auxiliary gas, $30 \mathrm{psi}$; ion source temperature, $500^{\circ} \mathrm{C}$.

Separations were achieved using a Shimadzu Shim-pack XRODSII column $(2.0 \times 100 \mathrm{~mm}, 2.2 \mu \mathrm{m}$ particle size $)$ and a Phenomenex Synergi Fusion-RP column $(2.0 \times 50 \mathrm{~mm}, 2.5 \mu \mathrm{m}$ particle size $)$. The column temperature was set to $60^{\circ} \mathrm{C}$.

The samples were injected into the LC-MS/MS system under the following conditions: flow rate, $0.5 \mathrm{~mL} / \mathrm{minute}$; injection volume, $5 \mu \mathrm{L}$; column furnace temperature, $60^{\circ} \mathrm{C}$; automatic sampler temperature; $20^{\circ} \mathrm{C}$; and total run time, 13 minutes. These conditions were established internally by the laboratory and were used after validation in studies (Oliveira et al. 2018).

For the mobile phase, used throughout the experiment, phase A was the aqueous fraction composed of a mixture of aqueous ammonium acetate solution $10 \mathrm{mmol} / \mathrm{L}$ acidified with $0.1 \%$ formic acid, and phase B was an organic fraction, comprising methanol.

Calibration curves were obtained using acetonitrile as a solvent to standardize the results of recovery and simplify the experiment. The following concentrations were used for calibration: 5.0, 7.5, $10.0,25.0,50.0,75.0$ and $100 \mu \mathrm{g} . \mathrm{kg}^{-1}$. All solutions were prepared independently. For the purpose of simultaneous quantification and identification, two or three multiple reaction monitoring (MRM) transitions were used for each analyte to avoid false negatives at trace pesticide levels. The peaks were evenly distributed along the chromatographic window and were resolved symmetrically. Data were analyzed using the Analyst program (Version 1.5.1, Applied Biosystems). The regression curve model for each compound was selected using a homoscedasticity test. The quality of fit and significance of the employed regression model were evaluated using the lack-of-fit test. The limit of detection (LOD) and the limit of quantification (LOQ) for all tested pesticides were determined to be 5.0 and $10.0 \mathrm{ppb}$, respectively. 
All analytical reagents used had a purity of $>98 \%$ and were purchased from Riedel-de Haën grade PESTANAL (Seelze, Germany) or Sigma-Aldrich (Saint Louis, USA).

\section{RESULTS}

A summary of the case and animal identification, the anatomopathological conclusions from the necropsy reports, microscopic examination and toxicological results are enumerated in Table 1.

All the cadavers were in excellent conditions because they were kept in a cold room. Within this study, we detected
8 different pesticides and their metabolites in bone marrow (Table 1). Measured concentrations of all compounds were higher than the LOD (5.0 ppb), but lower than the LOQ (10.0 ppb).

\section{DISCUSSION}

The main purpose of this study was not to propose that the toxicological examination of the viscera is substituted by that of bone marrow, but to demonstrate that the bone marrow may be a good choice as a sampling site for toxicological screening. The bone marrow is a highly vascularized tissue, well

Table 1. Identification of animals, clinical signs, anatomopathological conclusions and results of toxicological analyses by LC-MS

\begin{tabular}{|c|c|c|c|c|c|c|}
\hline Animal & Specie & Sex/Age & Clinical signs & Anatomopathological results & $\begin{array}{l}\text { Microscopic } \\
\text { examination }\end{array}$ & $\begin{array}{c}\text { Toxicological } \\
\text { analyses }\end{array}$ \\
\hline 1 & $\begin{array}{l}\text { Feline/ } \\
\text { Mixed- } \\
\text { breed }\end{array}$ & $\begin{array}{l}\text { Male/11 } \\
\text { months }\end{array}$ & $\begin{array}{l}\text { This cat was found } \\
\text { dead without any } \\
\text { clinical signs or } \\
\text { prior disease }\end{array}$ & $\begin{array}{l}\text { Macroscopically, the animal had cyanotic } \\
\text { external mucous membranes, epistaxis, } \\
\text { hyperemic and edematous lungs and multifocal } \\
\text { hemorrhages. The liver, spleen and kidneys were } \\
\text { moderately hyperemic. The esophageal and } \\
\text { stomach content revealed numerous rounded, } \\
\text { blackened and firm millimetric structures with } \\
\text { an appearance suggestive of aldicarb pesticide. } \\
\text { The anatomopathological conclusion was acute } \\
\text { respiratory insufficiency with a generalized } \\
\text { circulatory disorder. }\end{array}$ & $\begin{array}{l}\text { Lungs, liver, spleen } \\
\text { and kidneys were } \\
\text { hyperemic. }\end{array}$ & $\begin{array}{l}\text { Aldicarb } \\
\text { Aldicarb sulfone } \\
\text { Asulam } \\
\text { Carbendazim }\end{array}$ \\
\hline 2 & $\begin{array}{l}\text { Feline/ } \\
\text { Mixed- } \\
\text { breed }\end{array}$ & $\begin{array}{l}\text { Male/6 } \\
\text { months }\end{array}$ & $\begin{array}{l}\text { This cat was taken } \\
\text { to emergency } \\
\text { veterinary care } \\
\text { due to the sudden } \\
\text { appearance of } \\
\text { respiratory and } \\
\text { neurological } \\
\text { symptoms }\end{array}$ & $\begin{array}{l}\text { The main findings were pulmonary hyperemia, } \\
\text { edema and multifocal hemorrhages. Hyperemia of } \\
\text { the spleen, liver, kidneys, and leptomeninges was } \\
\text { observed. The anatomopathological conclusion } \\
\text { was generalized circulatory disorder. }\end{array}$ & $\begin{array}{l}\text { Edema and multifocal } \\
\text { hemorrhages in lungs. } \\
\text { Spleen, liver, kidneys, } \\
\text { and leptomeninges were } \\
\text { hyperemic. }\end{array}$ & $\begin{array}{l}\text { Aldicarb } \\
\text { Carbendazim } \\
\text { Trifloxysulfuron }\end{array}$ \\
\hline 3 & $\begin{array}{l}\text { Feline/ } \\
\text { Mixed- } \\
\text { breed }\end{array}$ & $\begin{array}{l}\text { Female/1 } \\
\text { year }\end{array}$ & $\begin{array}{l}\text { This cat presented } \\
\text { with prostration, } \\
\text { sialorrhea, vomiting } \\
\text { and tremors, } \\
\text { and was taken } \\
\text { into emergency } \\
\text { veterinary care }\end{array}$ & $\begin{array}{l}\text { Macroscopically, the animal displayed cyanotic } \\
\text { external mucous membranes, epistaxis, } \\
\text { hyperemic and edematous lungs and multifocal } \\
\text { hemorrhages. The liver, spleen and kidneys were } \\
\text { intensely hyperemic. The anatomopathological } \\
\text { conclusion was acute respiratory insufficiency } \\
\text { with a generalized circulatory disorder. }\end{array}$ & $\begin{array}{l}\text { The main findings were } \\
\text { pulmonary hyperemia, } \\
\text { edema with } \\
\text { multifocal hemorrhage, } \\
\text { and intense hyperemia } \\
\text { of the liver, kidneys and } \\
\text { leptomeninges. }\end{array}$ & Dichlorvos \\
\hline 4 & $\begin{array}{l}\text { Canine/ } \\
\text { Mixed- } \\
\text { breed }\end{array}$ & $\begin{array}{l}\text { Male/ } \\
\text { Unknown }\end{array}$ & $\begin{array}{l}\text { Unknown medical } \\
\text { history }\end{array}$ & $\begin{array}{l}\text { The animal had hyperemic external mucous } \\
\text { membranes, and the lungs showed moderate } \\
\text { hyperemia and edema. The liver, spleen, kidneys, } \\
\text { and leptomeninges were intensely hyperemic. The } \\
\text { anatomopathological conclusion of necropsy was } \\
\text { generalized circulatory disorder. }\end{array}$ & $\begin{array}{l}\text { The lungs showed } \\
\text { moderate hyperemia } \\
\text { and edema. The liver, } \\
\text { spleen, kidneys, and } \\
\text { leptomeninges were } \\
\text { intensely hyperemic. }\end{array}$ & $\begin{array}{l}\text { Aldicarb } \\
\text { Chlorpyrifos } \\
\text { Thifensulfuron- } \\
\text { methyl }\end{array}$ \\
\hline 5 & $\begin{array}{l}\text { Canine/ } \\
\text { Border } \\
\text { collie }\end{array}$ & $\begin{array}{l}\text { Female/1 } \\
\text { year }\end{array}$ & $\begin{array}{l}\text { The animal was } \\
\text { found dead with no } \\
\text { clinical signs }\end{array}$ & $\begin{array}{l}\text { Hyperemia of the external mucous membranes, } \\
\text { lymph nodes, musculature, liver, kidneys and } \\
\text { leptomeninges. The lungs showed moderate } \\
\text { hyperemia and edema, in addition to multifocal } \\
\text { hemorrhages. In the heart, there was an } \\
\text { area of hemorrhage in the epicardium. The } \\
\text { anatomopathological conclusion of necropsy was } \\
\text { generalized circulatory disorder. }\end{array}$ & $\begin{array}{l}\text { Pulmonary hyperemia, } \\
\text { edema with multifocal } \\
\text { hemorrhage, and } \\
\text { intense hyperemia in } \\
\text { the liver, kidneys, and } \\
\text { heart. }\end{array}$ & Aldicarb \\
\hline 6 & $\begin{array}{l}\text { Canine/ } \\
\text { Golden } \\
\text { Retriever }\end{array}$ & $\begin{array}{l}\text { Male/5 } \\
\text { years }\end{array}$ & $\begin{array}{l}\text { The animal } \\
\text { presented with } \\
\text { prostration, } \\
\text { vomiting and } \\
\text { diarrhea and } \\
\text { was taken to } \\
\text { an emergency } \\
\text { veterinary care }\end{array}$ & $\begin{array}{l}\text { Cyanotic external mucous membranes, epistaxis } \\
\text { and hyperemic and edematous lungs. The } \\
\text { liver, kidneys, and muscles were intensely } \\
\text { hyperemic and the heart showed hemorrhages } \\
\text { in the endocardium and epicardium. The } \\
\text { anatomopathological conclusion was neutrophilic } \\
\text { and fibrinous myocarditis with generalized } \\
\text { hyperemia. }\end{array}$ & $\begin{array}{l}\text { Neutrophilic and } \\
\text { fibrinous myocarditis } \\
\text { in the heart with focally } \\
\text { extensive hemorrhage, } \\
\text { hyperemia in the } \\
\text { stomach and kidneys, } \\
\text { pulmonary hyperemia, } \\
\text { and edema were } \\
\text { observed. }\end{array}$ & Not detected \\
\hline
\end{tabular}


protected by bone, and its lipid matrix may act as a repository for chemical agents. This may be particularly important when the carcass is in an advanced stage of decomposition or skeletonization.

One of the greatest difficulties during sample collection was the small amount of bone marrow present in each bone. Therefore, the collection of bone marrow from various bones (femur, humerus, and tibia) to generate a pool of bone marrow for each animal was necessary. In this study, the pool was used to provide the minimum amount of sample needed for extraction (5.0g) as per the QueChERS methodology and the assay. These bones were selected because they had a relatively larger medullary canal and, consequently, a greater amount of marrow in relation to the vertebrae and ribs. The LC-MS assay was able to detect the toxic chemicals in the bone marrow of five animals (Table 1 ). In addition, it was identified a greater number of toxicants (aldicarb, aldicarb sulfone, asulam, carbendazim, trifloxysulfuron, dichlorvos, chlorpyrifos, and thifensulfuron-methyl).

Aldicarb is a carbamate and is one of the most commonly chemicals used for criminal poisoning of animals (Xavier at al. 2007a, Siqueira et al. 2012). Aldicarb was detected in bone marrow of animals 1, 2, 4 and 5 and its metabolite, aldicarb sulfone (Harper et al. 1998) just in Feline 1. That is, it was found in $80 \%(4 / 5)$ of the poisoned animals. Aldicarb is extremely toxic to mammals and its toxicity is mediated through inhibition of acetylcholine esterase, a respiratory enzyme. All of these animals showed generalized circulatory disorders compatible with poisoning picture. The pesticide aldicarb known as "chumbinho", is one of the most toxic of registered pesticides, and has its use restricted to agriculture in Brazil. In spite of it, aldicarb is being very often involved in severe poisoning in animals (Xavier et al. 2007b). It is controlled in Brazil and is allowed only for agricultural uses upon prescription from a responsible technician. However, aldicarb is sold illegally for the extermination of domestic animals and is erroneously indicated as rat poison. As the marketing of aldicarb is illegal, to avoid detection during inspection, it is routinely mixed with other toxic substances in an unlabeled manner. Its use is justified by its high toxicity, ease of acquisition in the illegal trade, and inefficiency of the monitoring mechanisms (Xavier et al. 2017b). Our results agree with other reports of fatal cases of carbamate poisoning in dogs and cats in Brazil (Medeiros et al. 2009, Siqueira et al. 2015).

Asulam, a systemic herbicide highly effective against bracken, also was detected in Feline 1, and belongs to the group of carbamates - sulfanilylcarbamate. When administered orally or intravenously, it is excreted in the urine in 24 hours (Heijbroek et al. 1984). Kaufmann \& Kaenzig (2004) found sulfanilamide residues in 15 Swiss honeys out of some 350 samples. Bees occasionally collect nectar from meadows treated with the herbicide asulam. Such honey is not only contaminated by asulam, but also by its degradation product sulfanilamide. Carbamates pesticides can be divided into carbamate insecticides, mostly monomethyl carbamates, fungicidal dithiocarbamates and carbamates herbicides and fungicides. The toxicity of carbamate herbicides and fungicides is very heterogenous and its rather related to the aromatic moiety (herbicides) and the benzimidazole moiety (fungicides) than to the carbamate rest. Acute toxicity of carbamates herbicides and fungicides is generally low compared to the carbamate insecticides. However, as previously reported, Aldicarb is sold illegally, and many other substances could be added to this product, like the asulam.

The animals 3 and 4, showed other pesticides, from the organophosphorus group, also with action anti-acetylcholinesterase: dichlorvos (Feline 3) and chlorpyrifos (Canine 4). Dichlorvos is classified as highly toxic and it is used an agricultural insecticide on crops and stored products, besides as an antihelminthic for dogs, swine and horses, and to kill fly larvae. It is poisonous if swallowed, inhaled, or absorbed through the skin. The high dose of dichlorvos produces a detrimental effect on acetylcholinesterase activity (Verma et al. 2008).

Chlorpyrifos is an organophosphorothionate insecticide with nonsystemic anticholinesterase effects reported following exposure by skin contact, ingestion, or inhalation. It is one of the most widely used organophosphorus insecticides in the world. Chlorpyrifos has been widely used in agriculture, horticulture, viticulture and forestry on a wide range of crops, as well as in residential and nonresidential applications to control cockroaches, fleas, ticks on cattle and pests in animal dwellings (Sultatos 1994). The Feline 3 presented prostration and tremors, and the nervous system is the primary target because acetylcholinesterase and/or butlycholinesterase catabolyze the neurotransmitter acetylcholine, thereby terminating its synaptic function. The sialorrhea and vomiting also was presented by this animal are typical muscarinic signals showed in the anticholinesterase poisoning. It is well-established that severe poisoning by organophosphorus compounds strongly affects the cardiorespiratory system (Cunha et al. 2018).

Owing to its greater sensitivity, the LC-MS technique can be used to detect other toxin residues, including carbendazim, a fungicidal compound from the benzimidazole group; trifloxysulfuron-sodium, an herbicidal compound of the sulfonylurea class and thifensulfuron-methyl, a sulfonylurea herbicide. Our results confirmed the deposition of carbendazim within the bone marrow of Felines 1 and 2 (Table 1). The carbendazim is a highly effective, broad-spectrum, systemic fungicide used to protect fruits and other products from spoiling. and, it is relatively stable and persistent in the environment (Thomas et al. 1996). It is important to note that the presence of more than one type of chemical substance in the marrow bone has been detected in some animals (Feline 1, Feline 2 and Canine 4). The Feline 1 showed four substances in bone marrow, and this animal was found dead without any clinical signs or prior disease. Macroscopically, the esophageal and stomach content revealed numerous rounded, blackened, and firm millimetric structures with an appearance suggestive of aldicarb pesticide.

Besides the aldicarb and carbendazim, trifloxysulfuronsodium was found just in Feline 2. This cat was taken to emergency veterinary care due to the sudden appearance of respiratory and neurological symptoms. But, the clinical picture worsened, and this animal died. Trifloxysulfuron-sodium is a post-emergence herbicide without European Union regulatory approval for use. It has a high aqueous solubility, is relatively volatile and, based on its chemical properties, is mobile and may leach to groundwater in some situations. It is moderately persistent in soil systems but is generally non-persistent in aquatic systems. It has a low mammalian toxicity and has a high potential to bioaccumulate (PPDB 2020). 
Finally, the thifensulfuron-methyl was found in Canine 4. Thifensulfuron-methyl is a post-emergence herbicide for the control of grass and broad-leaved weeds and it is unlikely to presente an acute hazard. This herbicide has relatively long persistence in water and its partitioning into sediments is minimal. The sulfonylurea linkage in this compound is resistant to hydrolysis in weakly alkaline waters, and the microbial and photolytic degradation in dugout waters are slow (Cessna et al. 2006). Lazartigues et al. (2011) used the same extraction method (QuEChERS) and LC-MS to detect thifensulfuronmethyl on three fish species (in their muscles), naturally or orally exposed: roach (Rutilus rutilus), perch (Perca fluviatilis) and carp (Cyprinus carpio).

Brazil is one of the greatest consumers of pesticides in the world. Thus, the comparison of toxicological results with the clinical signs and anatomopathological findings is important to confirm whether the toxic chemicals found were related to the death of the animal. The success in the detection of toxic chemicals in human bone marrow was essentially dependent on the analytical method used and the methodology used in the pretreatment and extraction of the toxic chemicals from the sample, especially the adipose tissue matrix (Cartiser et al. 2011). In the present study, the QuEChERS extraction technique and the analytical method (LC-MS) were effective for the detection of pesticides in the bone marrow of cats and dogs. The degree of contact of drugs to the bone structures depends on the anatomical location of the bone and the local blood supply. The long bones (i.e., femur) receive the most blood supply while the short, flat, or irregular bones receive more superficial supply through the periosteum (Drummer 2008). Given this and the our results, the choice of femur, humerus and tibia bones was adequate.

In addition to the lack of studies in veterinary medicine that have investigated the detection of toxic chemicals in the bone marrow, there have been no studies in human forensic toxicology on the use of bone marrow for the detection of pesticides. Ackan et al. (2009) treated six rabbits with endosulfan and six with diazinon and collected bone marrow and analyzed by chromatography gas (GC-MS), and found these isomers and its metabolites in this sample. The authors concluded that cause of death can be determined as acute pesticide poisoning by toxicological analysis of samples from bone marrow.

Finally, the anatomopathological examination is very important and should always be accompanied by a toxicological examination in cases of suspected poisoning and may reveal pre-existing diseases that may not have been diagnosed antemortem. Canine 6 was the only one that did not show any pesticides in the bone marrow. The anatomopathological conclusion was neutrophilic and fibrinous myocarditis with generalized hyperemia.

Forensic toxicological analyses have traditionally focused the use blood, body fluids, and certain organs in examination of deaths due to poisoning. This study is preliminary, but showed that bone marrow might be used as an alternative specimen since it's a potential depot for pesticides.

\section{CONCLUSION}

Based on the results of this case study, we have concluded that bone marrow can be used for the detection of toxic chemicals to investigate poisoning in forensic veterinary medicine.
Aldicarb, aldicarb sulfone, asulam, carbendazim, chlorpyrifos, dichlorvos, thifensulfuron methyl and trifloxysulfuron were deposited in the bone marrow of cats and dogs and were detected by LC-MS analysis.

Acknowledgments.- We thank the "Conselho Nacional de Desenvolvimento Científico e Tecnológico" (CNPq) for the financial support (Process 305617/201/-6).

Conflict of interest statement.- We have no conflict of interest to declare.

\section{REFERENCES}

Ackan R., Hila A., Daglioglu N., Cekin N. \& Gulmen M.K. 2009. Determination of pesticides in postmortem blood and bone marrow of pesticide treated rabbits. Forensic Sci. Int. 189(1/3):82-87. <https://dx.doi.org/10.1016/j. forsciint.2009.04.017><PMid:19446970>

Anastassiades M., Lehotay S.J., Stajnbaher D. \& Schenck F.J. 2003. Fast and easy multiresidue method employing acetonitrile extraction/partitioning and "dispersive solid-phase extraction" for the determination of pesticide residues in produce. J. AOAC Int. 86(2):412-431. <PMid:12723926>

Cartiser N., Bévalot F., Fanton L., Gaillard Y. \& Guiltton J. 2011. State-of-theart of bone marrow analysis in forensic toxicology: a review. Int. J. Legal Med. 125(2):181-198. <https://dx.doi.org/10.1007/s00414-010-0525-6> <PMid:21061013>

Casier H., Thomas F. \& Delanouis A.L. 1943. La répartition de l'alcool chez l'homme et les animaux au cours de l'intoxication éthylique. Arch. Int. Pharmacodyn. 69:186-204

Cessna A.J., David B Donald D.B., Bailey J., Waiser M. \& Headley J.V. 2006. Persistence of the sulfonylurea herbicides thifensulfuron-methyl, ethametsulfuron-methyl, and metsulfuron-methyl in farm dugouts (ponds). J. Environ. Qual. 35(6):2395-2401. <https://dx.doi.org/10.2134/ jeq2005.0462 > <PMid:17071910>

Cunha A.F., Felippe I.S.A., Ferreira-Junior N.C., Resstel L.B.M., Guimarães D.A.M., Beijamini V., Paton J.F.R. \& Sampaio K.N. 2018. Neuroreflex control of cardiovascular function is impaired after acute poisoning with chlorpyrifos, an organophosphorus insecticide: possible short and long term clinical implications. Toxicology 398/399:13-22.<https://dx.doi.org/10.1016/j. tox.2018.02.005 > <PMid:29471072>

Drummer 0.H. 2008. Drugs in bone and bone marrow, p.131-137. In: Jenkins A.J. (Ed.), Drug Testing in Alternate Biological Specimens. Humana Press, New Jersey.

Fukushima A.R., Gonzalez M.V.D., Florio J.C., Salomone G.M., De-Siqueira A., Carvalho V.M., Zaccarelli-Magalhaes J., Anazawa T.A., Leoni L.A.B., Nicoletti M.A., Maiorka P.C. \& Spinosa H.S. 2018. Study of aldicarb commercial granule using dissolution profile: a contribution for identification of metabolites. Int. J. Curr. Innov. Res. 4(4):1173-1176.

Grellner W. \& Glenewinkel F. 1997. Exhumations: synopsis of morphological and toxicological findings in relation to the postmortem interval Survey on a 20-year period and review of the literature. Forensic Sci. Int. 90(1/2):139-159. <https://dx.doi.org/10.1016/S0379-0738(97)00154-0><PMid:9438373>

Harper F.D., Weisskopf C.P. \& Cobb G.P. 1998. Extraction of aldicarb and its metabolites from excreta and gastrointestinal tissue. Anal. Chem. 70(15):33293332. https://dx.doi.org/10.1021/ac971268k> <PMid:11013730>

Heijbroek W.M.H., Muggleton D.F. \& Parke D.V. 1984. Metabolism of the carbamate herbicide, asulam, in the rat. Xenobiotica 14(3):235-247. <https://dx.doi.org/10.3109/00498258409151408> <PMid:6711013>

Kaufmann A. \& Kaenzig A. 2004. Contamination of honey by the herbicide asulam and its antibacterial active metabolite sulfanilamide. Food Add. Cont. 21(6):564-571. https://dx.doi.org/10.1080/02652030410001677790> <PMid:15204534> 
Lazartigues A., Wiest L., Baudot R., Thomas M., Feidt C. \& Crein-Olivé C. 2011. Multiresidue method to quantify pesticides in fish muscle by QuEChERSbased extraction and LC-MS/MS. Anal. Bioanal. Chem. 400(7):2185-2193. <https://doi.org/10.1007/s00216-011-4945-z>

Maeda H., Zhu B.L., Ishikawa T., Oritani S., Michiue T., Li D.R., Zhao D. \& Ogawa M. 2006. Evaluation of post-mortem ethanol concentrations in pericardial fluid and bone marrow aspirate. Forensic Sci. Int. 161(2/3):141-143. <https://doi.org/10.1016/j.forsciint.2006.01.016><PMid:16842951>

McIntyre I.M., King C.V., Boratto M. \& Drummer O.H. 2000. Post-mortem drug analyses in bone and bone marrow. Ther. Drug Monit. 22(1):79-83. <https:// doi.org/10.1097/00007691-200002000-00017><PMid:10688265>

Medeiros R.J., Monteiro F.O., Silva G.C. \& Nascimento Junior A. 2009. Casos de intoxicações exógenas em cães e gatos atendidos na Faculdade de Veterinária da Universidade Federal Fluminense durante o período de 2002 a 2008. Ciência Rural 39(7):2105-2110. <https://dx.doi.org/10.1590/ S0103-84782009005000151>

Oliveira F.A.S., Pereira E.N.C, Gobbi J.M., Soto-Blanco B. \& Melo M.M. 2018. Multiresidue method for detection of pesticides in beef meat using liquid chromatography coupled to mass spectrometry detection (LC-MS) after QuEChERS extraction. Food Add. Cont., A 35(1):94-109. <https://doi.org /10.1080/19440049.2017.1395519><PMid:29058520>

PPDB 2020. Pesticides Propetiers DataBase, University of Hertfordshire, Hertfordshire. Available at <https://sitem.herts.ac.uk/aeru/ppdb/en/ Reports/1151.htm> Accessed on May 18, 2020.

Schloegl H., Rost T., Schmidt W., Wurst F.M. \& Weinmann W. 2006. Distribution of ethyl glucuronide in rib bone marrow, other tissues and body liquids as proof of alcohol consumption before death. Forensic Sci. Int. 156(2/3):213-218. <https://dx.doi.org/10.1016/j.forsciint.2005.03.024><PMid:15946814>

Siqueira A., Cassiano F.C., Landi M.F.A. Marlet E.F. \& Maiorka P.C. 2012. Non-accidental injuries found in necropsies of domestic cats: a review of 191 cases. J. Feline Med. Surg. 14(10):723-728. <https://dx.doi. org $/ 10.1177 / 1098612 X 12451374><$ PMid:22694958>

Siqueira A., Salvagni F.A, Yoshida A.S., Gonçalves-Junior V., Calefi A.S., Fukushima A.R., Spinosa H.S. \& Maiorka P.C. 2015. Poisoning of cats and dogs by the carbamate pesticides aldicarb and carbofuran. Res. Vet. Sci. 102:142-149. <https://dx.doi.org/10.1016/j.rvsc.2015.08.006><PMid:26412534>

Sultatos L.G. 1994. Mammalian toxicology of organophosphorus pesticides. J. Toxicol. Environ. Health 43(3):271-289. <https://dx.doi. org/10.1080/15287399409531921 ><PMid:7966438>
Thomas D.H., Loez-Ávila V., Betowsk L.D. \& Emom J.V. 1996. Determination of carbendazim in water by high-performance immunoaffinity chromatography on-line with high-performance liquid chromatography with diode-array or mass spectrometric detection. J. Chromatogr. A 724(1/2):207-217.

Verma S.K., Raheja G. \& Gill K.D. 2008. Role of muscarinic signal transduction and CREB phosphorylation in dichlorvos-induced memory deficits in rats: An acetylcholine independent mechanism. Toxicology 256(3):175-182. <https://dx.doi.org/10.1016/j.tox.2008.11.017>

Winek C.L. \& Esposito F.M. 1981. Comparative study of ethanol levels in blood versus bone marrow, vitreous humor, bile and urine. Forensic Sci. Int. 17(1):27-36. <https://dx.doi.org/10.1016/0379-0738(81)90185-7> $<$ PMid:7216079>

Winek C.L. \& Janssen J.K. 1982. Blood versus bone marrow isopropanol concentrations in rabbits. Forensic Sci. Int. 20(1):11-20. <https://dx.doi org/10.1016/0379-0738(82)90100-1>

Winek C.L. \& Jones T.1980. Blood versus bone marrow ethanol concentrations in rabbits and humans. Forensic Sci. Int. 16(2):101-109. <https://dx.doi. org/10.1016/0379-0738(80)90162-0> <PMid:7429375>

Winek C.L. \& Luhanik J.M. 1981. A storage study of ethanol in rabbit and human bone marrow. Forensic Sci. Int. 17(3):191-196. <https://dx.doi org/10.1016/0379-0738(81)90166-3><PMid:7239369>

Winek C.L., Costantino A.G., Wahba W.W. \& Collom W.D. 1985. Blood versus bone marrow pentobarbital concentrations. Forensic Sci. Int. 27(1):15-24. <https://dx.doi.org/10.1016/0379-0738(85)90100-8><PMid:3988192>

Winek C.L., Matejczyk R.J. \& Buddie E.G. 1983. Blood, bone marrow and eye fluid ethanol concentrations in putrefied rabbits. Forensic Sci. Int. 22(2/3):151-159. <https://dx.doi.org/10.1016/0379-0738(83)90008-7> $<$ PMid:6642341>

Winek C.L., Pluskota M. \& Wahba W.W. 1982. Plasma versus bone marrow flurazepam concentration in rabbits. Forensic Sci. Int. 19(2):155-163. <https://dx.doi.org/10.1016/0379-0738(82)90041-X>

Xavier F.G., Righi D.A. \& Spinosa H.S. 2007a. Fatal poisoning in dogs and cats: a 6-year report in a veterinary pathology servisse. Braz. J. Vet. Res. Anim. Sci. 44(4):304-309. <https://dx.doi.org/10.11606/issn.1678-4456. bjvras.2007.26632>

Xavier F.G., Righi D.A. \& Spinosa H.S. 2007b. Toxicology of the pesticide aldicarb ("chumbinho"): general, clinical and therapeutical features in dogs and cats. Ciência Rural 37(4):1206-1211. <https://dx.doi.org/10.1590/ S0103-84782007000400051> 